\title{
JUIZ CONSTITUCIONAL BRASILEIRO: A ATIVIDADE CRIATIVA AUSENTE DE PRINCÍPIOS LIMITADORES E A NEGAÇÃO DE UMA RESPONSABILIDADE POLÍTICA

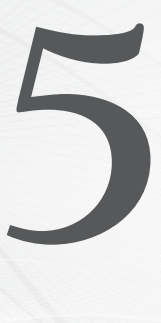

Constitutional brazilian judge: the creative activity away from limiting principles and the denial of political responsibility

Rafaela Benevides Ferreira Machado

Mestre em Direito pela Universidade de Toledo-SP (2009). Doutoranda em Direito pela Universidade de Coimbra (FDUC). Coordenadora do Grupo de Pesquisa da Universidade de Cuiabá. Componente do corpo docente da Universidade de Cuiabá, titular da disciplina Processo Constitucional. Pesquisadora do Núcleo de Pesquisa da UFMS e do Núcleo de Pesquisa do Centro Universitário Toledo de Ensino. Advogada.

Recebido em: 02.02.2012

Aprovado em: 01.03.2012

ÁreA do Direito: Constitucional

Resumo: 0 juiz constitucional brasileiro quando excede a sua real função de intérprete da Constituição, com intuito de sobrevalorizar principios, procurando de tal maneira atribuir sentidos normativos aos preceitos, acaba por invadir competências adstritas aos demais Poderes e por consequência desatende a sua "real" responsabilidade, portanto, cabível será o controle sobre ele. Eis a problemática central, apresenta-se: a ação politica desempenhada pelos juizes constitucionais brasileiros, especificamente os Ministros do STF, é caracterizadora de uma responsabilidade politica? Com a devida vênia, não se pode compac-

\begin{abstract}
AвSTRACT: The Brazilian constitutional court when it exceeds its actual role as interpreter of the Constitution, in order to overestimate principles, looking for a way to assign meanings to normative precepts, eventually invading powers attached to the other Powers and therefore pays no attention to their "real" responsibility, and therefore, is appropriate, therefore, will be the control over it. This is the central problem presents itself: political action performed by the Brazilian constitutional judges, especially the ministers of the Supreme Court, is characterizing a political responsibility? With due reverence, we
\end{abstract}


tuar com a interpretação constitucional criativa sem as suas devidas limitações principiológicas, i.e., não há uma responsabilização jurisdicional contundente e efetiva, o que há são juízes revestidos de poderes inabaláveis.

Palavras-chave: Juiz constitucional - Atividade criativa - Responsabilidade jurisdicional - Responsabilidade política. can not collude with the creative constitutional interpretation without its limitations of principles, i.e., there is not a forceful and effective judicial accountability, there are judges coated with unshakable power.

KeYwords: Constitutional judges - Creative activity - Jurisdictional responsibility - Political responsibility.

SumÁRıO: 1. Considerações iniciais - 2. Abordagem aos princípios limitativos propostos e a sua repercussão no exame do caso concreto: 2.1 Princípio da interpretação conforme a Constituição (interligado ao princípio da força normativa); 2.2 Princípio da autolimitação judicial em prol da segurança jurídica do Estado Democrático - 3. Responsabilidade do juiz constitucional - 4. Considerações finais - 5 . Referências bibliográficas.

"Para que os cidadãos politicamente autônomos possam ser considerados autores do direito, ao qual estão submetidos enquanto sujeitos privados é necessário que o direito legitimamente estatuido por eles determine a direção da circulação do poder político" (HABERMAS, Jürgen. Direito e democracia, entre facticidade e validade. Trad. Flávio B. Siebeneichler. Rio de Janeiro: Tempo Brasileiro, 1997. vol. 2. p. 12).

\section{Considerações Iniciais}

Partindo da premissa de que a atividade criativa dos juízes constitucionais brasileiros ganhou espaço amplo, no processo de "criação" do Direito, não só por complementar o trabalho do legislador, mas, também, por implementar políticas de Estado, é possível aferir, ab initio, que tais atividades funcionais são indignas de aplausos, especialmente quando estão presentes modus operandi calcado na discricionariedade "ilimitada". Desta feita, não se pode permitir e confiar ao juiz constitucional o papel de transformador da realidade social, afinal, cabe ao mesmo ser o intérprete constitucional ativo e não o "guardião republicano do processo político e da cidadania". ${ }^{1}$ Neste mesmo diapasão, "(...) a criatividade judicial supõe a violação do princípio da separação dos poderes e não será permitido legislar ex post ipso". ${ }^{2}$

1. Cattoni, Marcelo. Direito constitucional. Belo Horizonte: Mandamentos, 2002. p. 98.

2. Figueroa, Alfonso Garcia. Princípios y positivismo jurídico: el no positivismo principalista e las teorias de Ronald Dworkin y Robert Alexy. Madrid: Centro de Estudios Politicos y Constitucionales, 1998. p. 219. 
No presente estudo, juiz constitucional será compreendido, de forma genérica, como aquele que detém vinculação a norma hierarquicamente superior, ou seja, a Constituição Federal, logo, escolheu-se os Ministros do STF, diante da atividade criativa desempenhada com fomento pelos mesmos. Ademais, para que haja a evolução dogmática, far-se-á necessário dar os devidos apontamentos acerca da caracterização desta atividade criativa, ausente de princípios limitadores.

Eis a problemática central, apresenta-se: a ação política desempenhada pelos juízes constitucionais brasileiros, especificamente os Ministros do STF, é caracterizadora de uma responsabilidade política? Com a devida vênia, não se pode compactuar com a interpretação constitucional criativa sem as suas devidas limitações principiológicas, i.e., não há uma responsabilização jurisdicional contundente e efetiva, o que há são juízes revestidos de poderes inabaláveis. De fato, "confundir adequada e necessária intervenção da jurisdição constitucional com a possibilidade de decisionismo por parte dos juízes e tribunais é o mesmo que vitimizar o processo interpretativo constitucional e desviar o próprio sentido do Estado Democrático de Direito". 3

A primeira parte do trabalho corresponderá a uma análise por meio de dois princípios limitadores á atividade criativa, tais como: .os princípios da interpretação conforme a Constituição (interligado ao princípio da força normativa) e da autolimitação judicial em prol da segurança jurídica do Estado Democrático.Contudo tal tópico desenvolverá por meio de um caso concreto. O caso posto será: ADIn 4.277 e a ADPF 132/RJ, onde se reconheceram a união estável para casais do mesmo sexo.

A justificativa da escolha pondera entre a repercussão dada no Brasil, as multiplicidades de visões acerca desta decisão judicial e o seu desfecho, oposto a outros ordenamentos jurídicos que cuidaram de casos concretos semelhan-

3. Streck, Lenio Luiz. Verdade e consenso. Constituição, hermenêutica e teorias discursivas da possibilidade à necessidade de respostas corretas em direito. 2. ed. Rio de Janeiro: Lumen Juris, 2008.

A reflexão feita pelo autor Lenio Streck permite citar Antonio Manuel Peña Freire, em seu obra: Constitucionalismo garantista y democracia, p. 90. Para ambos, os juízes constitucionais devem garantir uma participação coletiva, no entanto limitada, para que não transgrida ao legislador. O autor Antonio Manuel Peña Freire, salienta: "que a prática é valiosa, quem sabe mereça ser protegida e garantida, evitando, por exemplo, que a maioria parlamentar possa solapar sem custo algum o poder dos juízes mediante uma reforma constitucional meramente formal". Merece atenção o pensamento ora esboçado, embora o presente estudo siga a linha de uma participação pautada em limites. 
tes. O que nos interessa é a função criativa sem critérios de limitação, portanto, exemplo este evidente de concretização. Nesta mesma linha de exposição o tópico também trará reflexões acerca da ausência de responsabilidade/controle perante esta função criativa ilimitada.

E por fim, a segunda parte pretenderá contextualizar o termo responsabilidade política, trazendo suas condições, consequências e os seus pressupostos, para que haja os devidos apontamentos acerca do questionamento suscitado pela presente análise reflexiva, ou seja, a ação política desempenhada pelos juízes constitucionais brasileiros, especificamente os Ministros do STF, é caracterizadora de uma responsabilidade política?

Neste diapasão haverá na presente exposição, uma divisão em duas partes, com um único intuito, responder ou pelo menos atentar a problemática elaborada.

\section{ABORdAGEM AOS PRINCÍPIOS LIMITATIVOS PROPOSTOS E A SUA REPERCUSSÃO NO EXAME DO CASO CONCRETO}

A análise crítica da problemática, na qual pese o presente estudo, não seria mais construtiva e satisfatória sem evidenciar o direito posto, já que o caso concreto é o elemento fundamental de constatação da atividade criativa ilimitada, desempenhada pelo juiz constitucional brasileiro.

Insta salientar a emblemática decisão do STF na ADIn 4.277 e a na ADPF 132/RJ, onde se reconheceram a união estável para casais do mesmo sexo.

Com intuito de demonstrar pontos fáticos desta função criativa ilimitada foram selecionados trechos de votos dos Ministros do STF. Por vezes, escolheram-se estes pela clareza e persistência em assumir a função anômala.

Conforme voto do rel. Ayres Brito:

"(...) Julgo procedentes as duas ações em causa. Pelo que dou ao art. 1.723 do Código Civil interpretação conforme a Constituição para dele excluir qualquer significado que impeça o reconhecimento da união contínua, pública e duradoura entre pessoas do mesmo sexo como 'entidade familiar', entendida esta como sinônimo perfeito de 'família'. Reconhecimento que é de ser feito segundo as mesmas regras e com as mesmas consequências da união estável heteroafetiva"4 (grifo nosso).

4. Brasil. STF. Julgamento da ADPF 132. Disponível em: [www.stf.jus.br]. Acesso em: 01.12.2011. 
Salientou o Min. Marco Aurélio:

“(...) Há, isso sim, a obrigação constitucional de não discriminação e de respeito à dignidade humana, às diferenças, à liberdade de orientação sexual, o que impõe o tratamento equânime entre homossexuais e heterossexuais. Nesse contexto, a literalidade do art. 1.723 do Código Civil está muito aquém do que consagrado pela Carta de 1988. Não retrata fielmente o propósito constitucional de reconhecer direitos a grupos minoritários. Por isso, Senhor Presidente, julgo procedente o pedido formulado para conferir interpretação conforme a Constituição ao art. 1.723 do Código Civil, veiculado pela Lei 10.406/2002, a fim de declarar a aplicabilidade do regime da união estável às uniões entre pessoas de sexo igual" (grifo nosso).

E por fim, não menos expressivo, o voto da Min. Cármem Lúcia:

“(...) E o pluralismo não apenas se põe, expressamente, no art. $1^{\circ}{ }^{\circ}, \mathrm{IV}$, da Constituição, como se tem também em seu preâmbulo, a sinalizar a trilha pela qual há de se conduzir o intérprete. As escolhas pessoais livres e legítimas, segundo o sistema jurídico vigente, são plurais na sociedade e, assim, terão de ser entendidas como válidas. Na esteira, assim, da assentada jurisprudência dos tribunais brasileiros, que já reconhecem para fins previdenciários, fiscais, de alguns direitos sociais a união homoafetiva, tenho como procedentes as ações, nos termos dos pedidos formulados, para reconhecer admissível como entidade familiar a união de pessoas do mesmo sexo e os mesmos direitos e deveres dos companheiros nas uniões estáveis serem reconhecidos àqueles que optam pela relação homoafetiva"6 (grifo nosso).

Exposto os julgados, calha agora aprofundar os argumentos dissonantes sobre os mesmos, por meio dos princípios propostos. Diante do direito "meramente reprodutor da realidade, passa-se a um direito com potencialidade de transformar a realidade."7 Neste contexto, as diversas facetas de interpretações e teorias são moldadas, com objetivos de construir interpretações as inúmeras situações da relação social, porém o obstáculo aparece quando o decisionismo e a discricionariedade ilimitada formam "corpo". É inexorável, então, a presença de princípios limitadores para obtenção de possíveis resultados práticos efetivos.

5. Idem, ibidem.

6. Idem, ibidem.

7. Streck, Lenio Luiz. Concretização de direitos e interpretação da Constituição. Boletim da Faculdade de Direito da Universidade de Coimbra, vol. LXXXI, p. 293. 


\subsection{Princípio da interpretação conforme a Constituição (interligado ao princípio da força normativa)}

A interpretação conforme a Constituição só será possível á luz do processo interpretativo constitucional, quando "houver espaço de decisão aberta a varias propostas interpretativas, proibindo-se a sua correção pelos Tribunais". 8

Além do mais, "em rigor não se trata de um princípio de interpretação da Constituição, mas de um princípio de interpretação da lei ordinária de acordo com a Constituição". ${ }^{9}$

Conforme, o autor J. J. Canotilho "o aplicador de uma norma não pode contrariar a letra e o sentido dessa norma através de uma interpretação conforme a constituição, mesmo que através desta interpretação consiga uma concordância entre a norma infraconstitucional e as normas constitucionais". ${ }^{10}$ Por sua vez, Luís Roberto Barroso faz a conexão entre o princípio em questão com os princípios da supremacia da Constituição e da presunção de constitucionalidade, seguindo a mesma linha de conceituação do autor J. J. Canotilho. Afinal, para "a interpretação conforme a Constituição pode envolver uma singela determinação de sentido da norma, sua não incidência a uma determinada situação de fato ou a exclusão. Naturalmente, o limite de tal interpretação está nas possibilidades semânticas do texto normativo". ${ }^{11}$ (grifo nosso).

$A b$ initio, não se pode afirmar que houve uma decisão conforme a Constituição. Interpretar o art. 1.723 do CC/2002 conforme a Constituição tem influência determinante na exegese, afinal o resultado alcançado pelos Ministros não fora determinado e nem concebido pelo legislador, portanto, tornando-se evidente uma decisão nova e distinta da Carta Magna. Mais uma vez, o juiz constitucional brasileiro colocou as vestes do legislador.

De acordo com António Castanheira Neves, "a interpretação jurídica é o ato metodológico de determinação do sentido jurídico-normativo de uma forma jurídica em ordem de obter dela um critério jurídico (um critério normativo de direito) no âmbito de uma problemática realização do direito e enquanto momento-normativo dessa mesma realização". ${ }^{12}$

8. Canotilho, José Joaquim Gomes. Direito constitucional e teoria da Constituição. 7. ed. Coimbra: Almedina, 2003.

9. Bonavides, Paulo. Curso de direito constitucional. São Paulo: Malheiros, 1993.

10. Canotilho, José Joaquim Gomes. Ob. cit., p. 1151.

11. Barroso, Luís Roberto. Ob. cit., 263.

12. Castanheira Neves, António. Metodologia jurídica. Digesta. Coimbra: Coimbra Ed., 1995. vol. 2. p. 83. 
Ademais, Francisco de Borja Lopez-Jurado Escribano, no direito comparado, faz menção da interpretação jurídica feita pelos Tribunais, interpretação calcada em uma discricionariedade sem precedentes. ${ }^{13}$

Contudo, criar ou desmantelar normas constitucionais ou deliberar correções indevidas por meio de decisões judiciais são práticas tendenciosas e perigosas. Contudo, decisões distorcidas ou frutos de invenções estariam arraigados de subjetivismo e o mais perigoso incentivaria a função criativa alargada.

\subsection{Princípio da autolimitação judicial em prol da segurança jurídica do Estado Democrático}

A autolimitação judicial ou judicial self restraint ${ }^{14}$ vem com intuito de fomentar a aplicação de mais um princípio limitativo ao processo de interpretação constitucional criativo, possibilitando o ativismo do juiz constitucional em suas decisões, mas por meios legítimos. Por vezes, deve sim existir limitações, quando estão em "jogo" "controle sobre normas inexistentes ou na carência do texto legal, omissões legislativas". 15

Os Ministros do STF não estão instituídos a preencher lacunas advindas do legislativo ${ }^{16}$ e muito menos serem transformadores da realidade social. No mesmo sentido o autor Francisco de Borja Lopes-Jurado Escribano, em seu

13. Escribano, Francisco de Borja Lopez-Jurado. La formulacion de critérios de interpretacion de la Constitución en la doctrina Alemana: parámetros de admisibilidad. Revista Española de Derecho Constitucional, ano. 12, n. 34, p. 123.

Neste sentido as palavras do autor: "Sólo los Tribunales Constitucionales rompen, diariamente, com sus decisiones, El circulo vicioso que supondría la necessidad de interpretar los critérios interpretativos. El problema de la determinacion de los critérios interpretativos es, en buena medida, el problema de la motivación de las sentencias; el problema de qué materiales pueden utilizar los Tribunales para construirlas. Es una cuestión de autolimitación".

14. Canotilho, José Joaquim Gomes. Ob. cit.

15. Castro, Flávia de Almeida Viveiros de. Novas técnicas de interpretação constitucional. RDCI 34/145.

16. O juiz constitucional deixa de ter comportamento inerte e escravo da lei, para que atue de forma ativa nas relações sociais. Porém, tal atitude está sendo alicerce e vem fomentando a omissão/inércia do Poder Legislativo, principalmente no tocante as políticas públicas.

A atuação ativista deixa de ter sinais positivos para tornar um problema, ou melhor, a atuação exacerbada do juiz constitucional/STF (especificando) no tocante as suas interpretações constitucionais não deve ser usada como "desculpa" para a falácia dos 
trabalho, analisa à luz do Direito Alemão, posto que para o autor não se possa declinar o exercício do Tribunal em favor de outros Órgãos Constitucionais sem afetar o sistema como um todo. ${ }^{17}$

Merece a devida atenção, o presente estudo entende que são inevitáveis as interpretações ativas criativas do juiz constitucional, até porque "a Constituição já não mais se restringe ao estabelecimento de limites aos poderes estatais e procura organizar a articulação e os limites da formação política da vontade e do exercício do domínio (...), ${ }^{18}$ já que não há novidade a mudança de paradigma vivenciada no pós-positivismo, a lei deixa de ter sua centralidade, portanto se evidencia a chamada "dessacralização da lei, ${ }^{19}$ além do mais, o Poder Legislativo não possui todas as respostas e métodos possíveis! Contudo, é obscuro a inversão do ônus feita pelo STF, i.e., o Judiciário é visto como o "criador", o próprio legislador positivo.

Então, no Brasil há um órgão de cúpula exercendo papel de "senhorio" da Constituição? A resposta torna-se afirmativa, ao suscitar três pontos: primeiro ponto, há formação de outro Poder dentro da mesma organização, no entanto, com uma nova face metódica (apesar de entender que o Tribunal é um instrumento limitado pela hierarquização das normas); o segundo, em uma sociedade de conflitos desarmônicos aderiram a este Tribunal ampla margem de discricionariedade, fazendo com que as suas decisões fossem pautadas por princípios abertos (não mais vetores); e o terceiro ponto seria o mais gravoso, a atividade criativa sem quaisquer limites tem plena aceitação do Poder Constituinte Originário, i.e., plena aceitação do povo. De fato, há inegáveis posturas dos Ministros em desenvolver a função criativa sem atentar aos princípios limitadores, negando, por sua vez, o constitucionalismo racional normativo. ${ }^{20}$

demais Poderes. Reitero, relegar ao juiz constitucional o papel de transformador da realidade social é o mesmo que trazer o desequilíbrio do sistema.

17. Escribano, Francisco de Borja Lopez-Jurado. Ob. cit., p. 125. Neste mesmo diapasão: "o Tribunal Constitucional é e deve permanecer o guardião da Constituição. Não pode exercer o papel dos outros órgãos constitucionais, o sistema como um todo vai sofrer".

18. Bockenforde, Ernst-Wolfgang. Estudios sobre el Estado de Derecho y la democracía. Madrid: Trotta, 2000.

19. Favoreu, Louis. A evolução e a mutação do direito constitucional francês. Direito constitucional - Estudos em homenagem a Manoel Gonçalves Ferreira Filho. São Paulo: Dialética, 1999. p. 215.

20. Carl Schmitt sustentava que o Poder legítimo racional, dentre as diversas formas de legitimidade, era baseado na legalidade, chamando de constitucionalismo racional normativo. 
Vale em último termo frisar, os verdadeiros interessados em limitar a discricionariedade dos juízes são os "senhores" da democracia, portanto, o povo.

Diante deste quadro desenhado, a dinamização anômala constatada e praticada pelos Ministros, fica evidente a sua responsabilização, portanto, cabível o controle. Por vez, é inconcebível a crença da irresponsabilidade Tribunal brasileiro, além do mais, "a responsabilidade não pode ser consequência do exercício do poder, mas antes e tão só, do abuso do poder ou, o mesmo dizer, dos desvios à sujeição á lei que sobre aqueles impende". ${ }^{21}$

\section{ReSPONSABILIDADE DO JUIZ CONSTITUCIONAL}

No que pese ao Poder Judiciário, ${ }^{22}$ encontra-se em sua independência funcional a matriz e a "direta exigência, imprescindível de um Estado de Direito, enquanto que a responsabilidade outorgada aos componentes deste poder o seu contrapeso". ${ }^{23}$ Assim, independência e responsabilidade são duas caras da mesma moeda, afinal o juiz independente também é responsável pelos seus atos. $^{24}$

De fato, o que se deve ater é na independência como valor instrumental e relativo, o Poder Judicial está ligado intimamente aos demais Poderes, como assevera Alberto Esteves Remédio. Para o autor a independência tem limites e que passam pela responsabilização judicial. ${ }^{25}$

A independência funcional dos juízes e a sua responsabilidade associam-se em dois aspectos: independência interligada ao "poder-dever" de decidir e a

21. Afonso, Orlando Viegas Martins. Poder judicial. Coimbra: Almedina, 2004.

22. Não seria mais apropriado o termo "Autoridade Judiciária" e não "Poder Judiciário"? Uma vez que, o termo "autoridade", no sentido político, não significaria um poder pleno, mas sim, "o braço secular do poder político". Portanto seria colocar o juiz num plano de sujeição a hierarquização ou a sua funcionalização. Pensamento este preconizado pelo autor Orlando Viegas Martins Afonso, ob. cit., p. 42-43.

23. Castanheira Neves, António. O atual problema dos assentos e a função jurídica dos Supremos Tribunais. Coimbra: Coimbra Ed., 1983.

$\mathrm{O}$ autor divide a independência funcional, material, aquela que há de garantir ao juiz em função, em dois aspectos: independência subjetiva e objetiva. Sendo que sua preocupação restringe em compreender a independência material, enquanto princípio do Estado de Direito.

24. Carretero, Juan Pedro; Sánchez-Diezma, Javier; Acosta, Luis; Testaut, Pedro; Pozo, Miguel. La responsabilidad personal del juez. Navarra: Aranzadi, 2008.

25. RemÉDio, Alberto Esteves. Sobre a responsabilidade civil dos magistrados por actos praticados no exercício das suas funções. Revista do Ministério Público, n. 88, ano 22, p. 31. 
independência no sentido de alcançar o direito como justiça, ou seja, aspecto político-jurídico e axiológico-jurídico.

Propomo-nos aqui a seguir a linha peculiar do autor António Castanheira Neves, ${ }^{26}$ o sentido político-jurídico coaduna com o princípio da independência dos Tribunais, implicando por meio de uma estrutura definida por outro princípio, a separação dos poderes. O sentido axiológico-jurídico assume a postura de definição de uma garantia, indispensável para a realização do direito e da justiça, aliás a justiça tem em sua essência o juiz ativista. A junção de definições feita, entre a independência funcional e a responsabilidade jurisdicional postula na liberdade de cada juiz na concreta decisão jurídica, ou seja, em sua liberdade de julgar.

Neste mesmo diapasão, liberdade de julgar, não poderia estar acima e muito menos servindo de guarida para a irresponsabilidade judicial, a garantia almejada não seria sustentáculo de irresponsabilidades, sendo eles juízes em um Estado Democrático, responsáveis pela movimentação do próprio sistema e garantidores, por consequência, do princípio da separação dos poderes. Por vezes, se não o fazem ou extravazam sua competência, demonstram serem passíveis de sanções, ao menos disciplinar. ${ }^{27}$

Afinal, a independência funcional é uma "justiça não subordinada a razões de Estado ou a interesses políticos, econômicos contingentes". ${ }^{28}$

Embora não seja o locus do presente estudo, é lícito salientar que a questão já não paira em saber se os juízes possuem ou não responsabilidade dentro de suas atividades, mas quem seriam os seus efetivos controladores (quis custodes custodiet)? Pelo menos no Brasil, em Portugal e na Espanha, não se vê responsabilização jurisdicional contundente e "real", o que se vê são juízes revestidos de Poderes inabaláveis. E neste mesmo sentido estão os ministros dos STF.

Outra causa está associada à possível atuação participativa sem critérios dos juízes constitucionais brasileiros em ações de natureza política, o que torna diferente do caráter menos instrumental e ativo, em sentido democrático. ${ }^{29}$

A efetividade da ideia de um juiz ativo que exerce atividade estritamente de natureza política depara-se sempre com o princípio da sujeição do juiz a lei,

26. Castanheira, Neves António. Ob. cit.

27. Ribeiro, Fávila. O problema da responsabilidade no governo democrático moderno. Ceará: Curso de Artes Gráficas da Escola Industrial Federal, 1965.

28. Afonso, Orlando Viegas Martins. Ob. cit., p. 67.

29. Cappelletti, Mauro. Juízes irresponsáveis? Porto Alegre: Sergio Antonio Fabris Ed., 1989. p. 33. 
sua vinculação prévia com a Constituição Federal. O Tribunal tem a missão precípua de intérprete da Constituição e não formador de políticas públicas, apesar de existir participação da Corte Suprema no debate jurídico-político, o seu objetivo está legitimamente direcionado por vetores intransigentes das normas constitucionais (Tribunal institucionalmente a serviço da Carta Magna). ${ }^{30}$

Nesta mesma esteira, as palavras de José Alcebíades de Oliveira Junior: “A Constituição mantém e sofistica o império da lei na atuação judicial, obviamente, não de uma maneira mecânica, porém, longe de se poder falar em uma liberdade absoluta". 31

Diante disso se coloca então o interrogante, se as ações de cunho político podem significar aos juízes constitucionais brasileiros uma responsabilidade política?

A resposta viria de pronto se entender a responsabilidade política na visão de Luis Esteban Delgado Del Rincón: “a sujeição dos juízes ao poder político mediante o controle que este pode ter sobre a nomeação e a confirmação dos juízes, sobre o exercício concreto da atividade jurisdicional, sobre a promoção profissional, ou também, sobre a gestão dos instrumentos de responsabilidade disciplinar". 32

No entanto, quando se aborda, por outra perspectiva, a questão da responsabilidade política do juiz constitucional brasileiro, entende a negar a sua existência, admitindo, por consequência, as vertentes clássicas da responsabilidade jurídica, ${ }^{33}$ apesar de existirem pontos que possuem marcas similares dos critérios políticos.

Então, cabe aqui atentar ${ }^{34}$ de forma sequencial os três pontos, na qual se enquadra aos critérios políticos.

30. SANCHEZ, Miguel Revenga. Función jurisdiccional y control político. Revista Española de Derecho Constitucional, n. 29, ano. 10, p. 122.

31. Oliveira Junior, José Alcebíades de. Reflexões sobre responsabilidade política e sociocultural dos magistrados. Revista do Direito Unisc 33/2.

32. Rincón, Luis Esteban Delgado Del. La responsabilidad política y social Del poder judicial. Madrid: Centro de Estudios Políticos y Constitucionales, 2002.

33. Cappelletti, Mauro. Ob. cit., p. 92.

34. Estes três pontos suscitados foram embasados pelo autor Luis Esteban Delgado Del Rincón, conforme se segue: 1 - A avaliação das condutas ou comportamento dos juízes pode ser segundo critérios de oportunidade e não de estrita legalidade; 2 - O caráter político do órgão ante o qual se depura a responsabilidade, podendo a responsabilidade ser exigida em última instância pela opinião pública; 3 - O caráter também 
1. Evidenciam-se critérios de oportunidade, quando as suas interpretações são direcionadas pela discricionariedade aberta (ponto este falho).

2. O caráter político do órgão em que se depura a responsabilidade dos ministros do STF. No caso em questão, o Senado Federal, conforme o art. 52, II, da CF/1988.

3. A perda do cargo ou o elemento sancionatório é característico de uma responsabilidade política. No caso, o impeachment.

Pode-se dizer simplesmente que, não se pode definir e nem justificar a responsabilização política sob dois argumentos: o procedimento do julgamento for feito pelo Senado Federal, órgão político e a sua sanção legal ser o impeachment, pena política. É preciso desmistificar a associação mecânica que se estabelece entre a real permanência deste instituto com a existência de sanção. $\mathrm{Na}$ linha defendida pelo autor espanhol Aragón Reyes, a sanção seria a última etapa da responsabilidade política e não se justifica a sua existência pelo resultado ser negativo, no que concede ao sujeito controlado. ${ }^{35}$

A título de história. Nos países do common law os juízes podem ser responsabilizados politicamente, podendo ser afastados do cargo por decisão das Cámaras, trazendo em seu procedimento o impeachment, além de possuírem o princípio do bom comportamento no exercício de suas funções. ${ }^{36}$

Ademais, "em termos de responsabilidade dos juízes, exaltam aspectos políticos, ao mesmo tempo não se admite a responsabilidade civil e menospreza ou rejeita a disciplinar". ${ }^{37}$

Ao contrário do sistema da civil law na qual se baseia fortemente nas responsabilidades disciplinares e civis, no entanto rejeitam qualquer tipo de responsabilidade política. Então, convém separar os sistemas da civil law dos sistemas do common law, no tocante a responsabilidade judicial.

Como se sabe, o Brasil adota a moldura do segundo sistema, a civil law; sendo que neste sistema não se adota o recrutamento e a nomeação dos juízes por

político do juízo ou procedimento que se para fazer a (sentença) efetiva; 4 - A perda do cargo ou a obrigação de demitir como elemento negativo ou sancionatório, é característico de uma responsabilidade política institucional.

35. ReYEs, Manuel Aragón. La interpretación de la Constitución y el carácter objetivado de control jurisdicional. Revista Española de Derecho Constitucional, n. 17, ano 6, p. 131.

36. Carretero, Juan Pedro; Sánchez-Diezma, Javier; Acosta, Luis; Testaut, Pedro; Pozo, Miguel. Ob. cit., p. 35.

37. Thomaz, Fernão de C. Fernandes. Da irresponsabilidade à responsabilização dos juízes. Revista da Ordem dos Advogados, vol. 2, ano. 54, p. 493. 
meio do critério de confiança, não podendo cogitar a responsabilidade política dos mesmos. ${ }^{38}$

Na verdade, por que há forte tendência da doutrina pátria em aceitar a responsabilização política dos ministros do Supremo?

A resposta estaria nas palavras da professora Maria Benedita Urbano em seu artigo Responsabilidade jurídica: baralhar para governar. Para ela vivemos em tempos de uma descaracterização do conceito de responsabilidade política, afetando de forma significativa a sua figura e de como ela será aplicada; permitindo como encaixe, no presente estudo, duas justificações feitas pela autora: a ampliação do âmbito do sujeito de responsabilização e o aproveitamento político a responsabilidade jurídica. ${ }^{39}$

Ademais, a realidade brasileira acaba por coadunar com a devida confusão de conteúdos, já que vem sendo permitido ou pelo menos aceitável aos Minitros do Tribunal solucionar ou "embaralhar" 40 casos concretos de seara política por vias jurídicas. Mas a solução viria desde logo, se houvesse uma devida efetividade de separação da jurisdição constitucional, da jurisdição ordinária, na qual permitiria uma real movimentação das demais instituições. ${ }^{41}$ Talvez um dos piores e o mais recente exemplo fora apresentado pelo presente estudo. $\mathrm{O}$ juiz, o próprio legislador.

Pois bem. De qualquer maneira, parece impossível apreciar a afirmação, quanto à negativa de responsabilidade política dos sujeitos alvos, se não se dispuser de contextualizar a significação da responsabilidade política com a responsabilidade assumida pelos ministros do STF.

Procurará responder fundamentalmente às seguintes perguntas: Os ministros do STF exercem atividade de natureza política? Em caso afirmativo, eles, então, ostentam poder político? Serão sujeitos de controle político e, por consequência, possuem independência de critérios, ou seja, "opções a fazer"?

Como aconselha $G$. Rescigno com sua obra intitulada La responsabilitá politica, a explicação da responsabilidade política deve começar pela relação entre responsabilidade e poder, ou seja, torna-se inaceitável na visão do autor, titu-

38. Afonso, Orlando Viegas Martins. Ob. cit., p. 145.

39. Maria Benedita Urbano em seu artigo Responsabilidade jurídica: baralhar para governar. Boletim da Ordem dos Advogados, n. 27.

40. Peço licença a autora Maria Benedita Urbano pelo uso do termo.

41. Esta ideia não é originalidade minha, no entanto cabe aqui fazer as futuras reflexões. Ver: Souza Junior, Cezar Saldanha. O tribunal constitucional como poder: uma nova teoria da divisão dos poderes. Porto Alegre: Memória, 2002. 
lares de cargo, poder, ou função, sem legitimidade democrática, sem representação política.

De qualquer forma, os ministros possuem responsabilidade de decidir, direcionados a garantir o Estado de Direito e não adstritos a um poder de âmbito político, na qual o princípio representativo se exige, ou por meio de eleições ou por formas legítimas e democráticas. Além do mais, este sujeito que detém o poder possui um mandato, significando temporalidade no cargo.

Claro, não se pode deixar de olvidar a formação de uma "democracia alargada" ${ }^{42}$ aquela em que há participação técnica cada vez mais ativa em planos políticos, como é o caso de peritos, especialistas tendentes a solucionar ou assegurar a proteção das liberdades ou praticar as vias de consenso.

Mas atendendo o estudo, o princípio representativo assenta num círculo: "o governo é representativo porque é escolhido democraticamente, e é responsável por ser representativo". ${ }^{43} \mathrm{Na}$ mesma linha, estaria a responsividade, elemento preponderante na caracterização da responsabilidade política, sua definição encontra-se na sujeição a cumprimentos de obrigações, "promessas" perante as aspirações do povo. ${ }^{44}$

Ora, a responsividade nada tem incomum com a responsabilidade-competência, na qual é assumida pelo juiz constitucional.

Não fugindo o objeto deste trabalho, fica claro o primeiro questionamento, os ministros não detêm e nem ostentam poder político, afinal, "o juiz da post modernidade é um juiz político, não político-partidário". ${ }^{45}$

Neste sentido, ser sujeito de controle político dentro deste instituto é o mesmo que adequar o sujeito ativo da relação com o controle externo, a grande valia encontra-se guarida nos tipos de responsabilidade política: a institucional, a difusa ou a institucional livre. Sendo ilógico estabelecer uma identificação deste tipo de sujeito com o sujeito alvo do presente estudo.

O sujeito de controle político é aquele que está próximo e comprometido com a comunidade que o envolve, ao contrário do juiz constitucional, pois este deve comprometimento com a isenção, ou como Orlando Afonso alude: "a isenção é o primeiro atributo do juiz justo" ${ }^{46}$ Então, estar isento significa ser

42. Afonso, Orlando Viegas Martins. Ob. cit., p. 52.

43. Lomba, Pedro. Teoria da responsabilidade política. Coimbra: Coimbra Ed., 2008. p. 79.

44. Idem, p. 92.

45. Afonso, Orlando Viegas Martins. Ob. cit., p. 87.

46. Idem, p. 66. 
sujeito não comprometido com suas pré-compreensões, nem com a sociedade que o circunda, mas estar sim vinculado com suas competências. Contudo, "o Juiz é, como dizem os ingleses, o sem par, o que não tem par, o que não tem igual, o que está fora das partes, o que não toma partido, salvo o partido da justiça". 47

O último questionamento está fadado à negação, pois o sujeito político deve possuir margens de liberdade, necessitando de "opções a fazer", portanto há duas dimensões inseparáveis deste sujeito, a liberdade e a discricionariedade nas suas decisões, como acentuou José Joaquim Gomes Canotilho. ${ }^{48}$

Ademais, Miguel Revenga Sanchez segue a mesma linha de caracterização, ${ }^{49}$ pois para ele, o primeiro critério de responsabilidade política atém-se em ostentar poder político, o segundo parâmetro equivale ao sujeito de controle político (capacidade de decidir livremente) e, o terceiro consiste na independência de critérios.

Finalmente, torna-se difícil aceitar a responsabilidade política como uma espécie de responsabilidade outorgada aos ministros do STF, uma vez que os elementos apresentados não se enquadram.

Dito isso e seguindo a construção, cabe dispor de olhares sobre o ordenamento jurídico brasileiro, com intuito de elucidar se há responsabilidade de tal espécie legalmente prevista.

Vejamos o elenco supra:

A Constituição Federal de 1988 prescreve em seu inc. II do art. 52, in verbis:

"Compete privativamente ao Senado Federal:

$\mathrm{I}-(\ldots)$;

II - processar e julgar os Ministros do Supremo Tribunal Federal, o Procurador Geral da República e o Advogado-Geral da União nos crimes de responsabilidade (grifo nosso).

Parágrafo único: Nos casos previstos nos incs. I e II, funcionará como Presidente o do Supremo Tribunal Federal, limitando-se a condenação, que somente será proferida por dois terços dos votos do Senado Federal, à perda do cargo, com inabilitação, por oito anos, para o exercício de função pública, sem prejuízo das demais sanções judiciais cabíveis" (grifo nosso).

47. Idem, ibidem.

48. Canotilho, José Joaquim Gomes. Ob. cit.

49. SAnChez, Miguel Revenga. Ob. cit., p. 119. 
Por fim, a Lei 1.079/1950 de 10 de abril, complementa a análise feita, em seu art. 39, in verbis:

"São crimes de responsabilidade dos Ministros do Supremo Tribunal Federal:

1 - alterar, por qualquer forma, exceto por via de recurso, a decisão ou voto já proferido em sessão do Tribunal;

2 - proferir julgamento, quando, por lei, seja suspeito na causa;

3 - exercer atividade político-partidária;

4 - ser patentemente desidioso no cumprimento dos deveres do cargo;

5 - proceder de modo incompatível com a honra, dignidade e decoro de suas funções" (grifo nosso).

Conforme exposto, os artigos prelecionados prescrevem em seus verbetes "crimes de responsabilidade" e não "responsabilidade política", contudo a responsabilidade do sujeito alvo não se amplia em sítios políticos. Aliás, cabe ratificar, a responsabilidade de fato traz consigo poderes perigosos. ${ }^{50}$

Obviamente, "não há notícia de que tenha sido admitido, por comissão especial, o processamento de denúncia contra o Ministro do STF", ${ }^{51}$ além da inoperância da Lei 1.079/1950.

Com devida anuência, qual tipo de responsabilidade/controle deve atuar como meio de impedir o exercício protagonista, desenfreado, favorecedora da função criativa sem limitações, da Corte Suprema, de cunho puramente político?

$\mathrm{Na}$ altura em que se discute, parece lógico atentar sobre este viés, no entanto não há um regime de responsabilidade atuante e qualificado que daria contornos precisos e com o grau de evolução caracterizado na Corte Suprema.

Como fora dito, responsabilidade existe e não parece ser este o problema, a questão paira na forma como irá se operacionalizar tal controle. Afinal, a responsabilização dos sujeitos está longe de ser obra acabada.

Resultados são almejados e mesmo assim não se entendeu, já que diante de um constitucionalismo tardio, encontra-se a única alternativa, por em prática a real democracia ou, será que se torna aceitável a concepção de Dworkin? Para ele as decisões relativas "a direitos, posto em confronto com as maiorias, não devem ser legitimamente deixadas à disposição das próprias maiorias". ${ }^{52}$

50. Construção esta feita por meio do diálogo que desenvolvo com a professora de doutoramento.

51. Ribeiro, Fávila. Ob. cit., p. 21.

52. Dworkin, Ronald. Taking rights seriously. London: Duckworth, 1997. 
Posto desta forma, a função criativa jurisprudencial parece ser a mão condutora encontrada para construção e resolução dos casos tidos como profundos, porém cabe sopesar entre os limites deste contorno e o devido respeito diante do Estado de Direito, no tocante a real função de cada instituição. Neste momento é necessário dar instrumentalidade ao instituto da responsabilidade diante da tutela jurisdicional, especificando o juiz constitucional.

\section{CONSIDERAÇÕES FINAIS}

Como corolário do que foi dito, poder-se-á dizer que o juiz constitucional brasileiro, quando transcende a sua real função de intérprete da Constituição, com intuito de sobrevalorizar princípios, procurando de tal maneira atribuir sentidos normativos aos preceitos, invade competências adstritas aos demais Poderes, desatendendo a sua responsabilidade funcional e, portanto cabível o controle.

Olvidou tomar como postura de que os sujeitos alvos, por ganharem espaço amplo no processo de criação do direito, complementando o trabalho do legislador ou implementando políticas de Estado, exercem atividades funcionais indignas de aplausos, posto que são calcadas na discricionariedade ilimitada.

A primeira parte do trabalho correspondeu a uma análise por meio de dois princípios limitativos a função criativa do sujeito alvo. Os princípios da interpretação conforme a Constituição (interligado ao princípio da força normativa) e da autolimitação judicial em prol da segurança jurídica do Estado Democrático. Contudo tal tópico desenvolveu-se por meio de um caso concreto.

Ademais, constatou-se que diante do caso concreto, não há por parte dos ministros do STF quaisquer sopesamento ou respeito diante dos princípios limitadores propostos.

Por consequência desta constatação, o questionamento fora levantado, ou seja, existe ou não controle/responsabilidade diante deste "poder"?

Infelizmente, os excessos advindos do decisionismo (fonte da função criativa ilimitada) não põe em causa o regime da responsabilidade sobre os controlados, além dos mais, o próprio sistema é ineficiente, quanto aos controladores.

Ora. Não se vê responsabilização jurisdicional contundente e ativa, o que se vê são juízes revestidos de poderes inabaláveis e, neste mesmo sentido estão os ministros dos STF.

Outro fruto advindo da função criativa ilimitada seria a atuação dos juízes constitucionais brasileiros em ações de natureza política, posto que se tornou aceitável aos ministros do tribunal solucionar casos concretos de seara política por vias jurídicas. 
Por tal realidade, novos contornos foram dados a responsabilização jurisdicional, pondo a responsabilidade política como outro meio de controle. Porém o presente estudo se ateve em negar tal menção, por meio da análise qualitativa (doutrinária).

Contudo a confusão de conceitos e contextualizações foi formada, causando o enfraquecimento do sentido concreto e efetivo da responsabilidade política e jurídica.

Mas merece atenção tal confusão, já que é visto pelo presente estudo como uma possibilidade de se buscar uma nova contextualização dos dois termos, desmistificando os devidos critérios da função política e jurídica.

Assim, a consideração final não deixaria de mencionar que os sujeitos alvos devem e buscam serem responsáveis, até porque o estatuto da responsabilidade funcional envolve o funcionamento do Estado de Direito. Mas, se agem de forma anômala ou se há uma "disfunção do Judiciário", expressão usada por Elival da Silva Ramos, ${ }^{53}$ é porque o sistema está sendo operacionalizado de forma incorreta. É errôneo "culpar" o enfraquecimento e ineficiência do Poder Legislativo diante dos inegáveis excessos; além do mais, também são evidenciados pelo Poder Executivo, visto as inúmeras medidas provisórias emitidas pelo Presidente da República.

Seria interessante dar como exemplo, em últimas palavras, a Constituição do Canadá, de 1982, posto que ela disponibilizaria a "cláusula não obstante", (notwithstanding clause), na qual o Poder Legislativo poderá ou não contrariar o texto constitucional, claro, na visão do Poder Judiciário, impondo um diploma normativo, fazendo com que o juiz constitucional não detenha a última palavra, incentivando de tal forma a valorização de pontos essências e democráticos; sendo que tal meio é exercido por meio do controle brando de constitucionalidade $e^{54}$ (Inglaterra, Nova Zelândia e Israel adotaram também o mecanismo).

Não penso na necessidade de repensar a cláusula da separação dos poderes, ${ }^{55}$ mas sim moldar de forma prática/ instrumental a organização das instituições,

53. Parâmetros dogmáticos do ativismo judicial em matéria constitucional. Tese apresentada à Faculdade de Direito, São Paulo, USP, 2009, p. 83 e ss.

Para o autor a expressão será usada quando, "o juiz ultrapassa os limites dados pelo texto normativo para garantir algo que não está escrito em lugar nenhum".

54. Pinto, José Guilherme Berman Corrêa. Supremacia judicial e controle de constitucionalidade. Revista de Direito Público. vol. 1, n. 31, p. 2.

55. Por mais que há pensamento eloquente pautado na separação dos poderes. Ver: SiLVA RAmos, Elival da. Ob. cit., p. 83 e ss. 
podendo ter maior racionalidade; o sujeito controlador e controlado da responsabilidade seria mais visto e respeitado. É um mal que urge minimizar não só no Brasil.

De facto, não há necessidade de alterações no regime de responsabilidade dos juízes constitucionais brasileiros, ${ }^{56}$ mas sim uma efetiva praticidade deste; contudo, o que mais se assevera é o valor fulcral do significado substancial do termo "responsabilidade do juiz constitucional brasileiro", ora, "(...) ao assegurar a vontade da Constituição, o STF realiza o ideal do governo das leis. Caso se afaste da vontade da Constituição, substituindo-a pela de seus próprios Ministros, estará agindo ilegitimamente, pois afinal não foram eleitos para assumir esse tipo de função e sequer a Constituição assegurou ao Tribunal tais atribuições. Ao STF, no entanto, cabe a última palavra. Daí a sua enorme responsabilidade". ${ }^{57}$

\section{REFERÊNCIAS BIBLIOGRÁFICAS}

Afonso, Orlando Viegas Martins. Poder judicial. Coimbra: Almedina, 2004.

Aguiar Júnior, Ruy Rosado de. Responsabilidade política e social dos juizes nas democracias modernas. Apresentado no V Congresso Internacional de Derecho de Daños, na Faculdade de Direito da Universidade de Buenos Aires em 24 e 25.04.1997. Porto Alegre: Ajuris, 1997.

BARROSO, Luís Roberto. Neoconstitucionalismo e constitucionalização do direito: o triunfo tardio do Direito Constitucional no Brasil. Boletim da Faculdade de Direito da Universidade de Coimbra-FDUC. vol. LXXXI. Coimbra: Coimbra Ed., 2005.

BOCKENFORDE, Ernst-Wolfgang. Estudios sobre el Estado de Derecho y la democracía. Madrid: Trotta, 2000.

Bonavides, Paulo. Curso de direito constitucional. São Paulo: Malheiros, 1993.

Brasil. Supremo Tribunal Federal. Disponível em: [www.stf.jus.br]. Acesso em: 01.12.2011.

Canotilho, José Joaquim Gomes. Direito constitucional e teoria da Constituição. 7. ed. Coimbra: Almedina, 2003.

Cappelletti, Mauro. Juizes irresponsáveis? Porto Alegre: Sergio Antonio Fabris Ed., 1989.

56. Quando menciono "regime de responsabilidade" não penso estar associado a ideia de lei, algo positivado, mas a compreensão exata da garantia, independência do juiz; como fora mencionado no presente artigo, independência e responsabilidade são duas caras da mesma moeda.

57. VIEIRA, Oscar Vilhena. Supremo Tribunal Federal: jurisprudência política, p. 233. 
Carretero, Juan Pedro; Sánchez-Diezma, Javier; Acosta, Luis; Testaut, Pedro; Pozo, Miguel. La responsabilidad personal del Juez. Navarra: Aranzadi, 2008.

Castanheira Neves, António. Metodologia jurídica. Digesta. Coimbra: Coimbra Ed., 1995. vol 2.

O atual problema dos assentos e a função jurídica dos Supremos Tribunais. Coimbra: Coimbra Ed., 1983.

Castro. Flávia de Almeida Viveiros de. Novas técnicas de interpretação constitucional. Revista de Direito Constitucional e Internacional. vol. 34. p. 134. São Paulo: Ed. RT, 2001.

Cattoni, Marcelo. Direito constitucional. Belo Horizonte: Mandamentos, 2002.

Dworkin, Ronald. Law's Empire. Disponível em: [www.nyu.edulfaculty]. Acesso em: 10.12.2011.

Taking rights seriously. London: Duckworth, 1997.

Escribano, Francisco de Borja Lopez-Jurado. La formulacion de critérios de interpretacion de la Constitución en la doctrina Alemana: parámetros de admisibilidad. Revista Española de Derecho Constitucional. n. 34. ano. 12. p. 99-126. Madrid: Centro de Estudios Políticos y Constitucionales, 1992.

FAVOrEU, Louis. A evolução e a mutação do direito constitucional francês. Direito constitucional - Estudos em homenagem a Manoel Gonçalves Ferreira Filho. São Paulo: Dialética, 1999.

Figueroa, Alfonso Garcia. Princípios y positivismo jurídico: El no positivismo principalista e las teorias de Ronald Dworkin y Robert Alexy. Madrid: Centro de Estudios Politicos y Constitucionales, 1998. Colección El Derecho y La Justicia.

Habermas, Jürgen. Direito e democracia entre faticidade e validade. Trad. Flávio B. Siebeneichler. Rio de Janeiro: Tempo Brasileiro, 1997. vol. 1 e 2.

Lomba, Pedro. Teoria da responsabilidade política. Coimbra: Coimbra Ed., 2008.

Loureiro, João; Machado, Jónatas; Urbano, Maria Benedita. Direito constitucional: casos práticos resolvidos. Coimbra: Coimbra Ed., 2010.

Miranda, Jorge. Manual de direito constitucional. 3. ed. Coimbra: Coimbra Ed., 1991. t. II.

Neto, Luísa. A (ir)responsabilidade dos juízes. Revista da Faculdade de Direito da Universidade do Porto. ano 3. Coimbra: Coimbra Ed., 2006.

Oliveira Junior, José Alcebíades de. Reflexões sobre responsabilidade política e sociocultural dos magistrados. Revista do Direito UNISC. n. 33. Santa Cruz do Sul: Edunisc, 2010.

PInTo, José Guilherme Berman Corrêa. Supremacia judicial e controle de constitucionalidade. Revista de Direito Público. vol. 1. n. 31. Lisboa: Instituto de Direito Público, 2010. 
RemÉDIO, Alberto Esteves. Sobre a responsabilidade civil dos magistrados por actos praticados no exercício das suas funções. Revista do Ministério Público. n. 88. ano 22. p. 31-49, 2001.

Rescigno, G. La responsabilità política. Milano: Giuffrè, 1967.

ReYes, Manuel Aragón. La interpretación de la Constitución y el carácter objetivado de control jurisdicional. Revista Española de Derecho Constitucional. n. 17. ano 6. p. 85-136. Madrid: Centro de Estudios Politicos y Constitucionales, 1986.

Ribeiro, Fávila. O problema da responsabilidade no governo democrático moderno. Ceará: Curso de Artes Gráficas da Escola Industrial Federal, 1965.

Rincón, Luis Esteban Delgado Del. La responsabilidad política y social Del poder judicial. Madrid: Centro de Estudios Políticos y Constitucionales, 2002.

SANCHEz, Miguel Revenga. Función jurisdiccional y control político. Revista Española de Derecho Constitucional. ano 10. n. 29. p. 117-142. Madrid: Centro de Estudios Politicos y Constitucionales, 1990.

Silva Ramos, Elival da. Parâmetros dogmáticos do ativismo judicial em matéria constitucional. Tese apresentada à Faculdade de Direito, São Paulo, USP, 2009.

Souza Junior, Cezar Saldanha. O tribunal constitucional como poder: uma nova teoria da divisão dos poderes. Porto Alegre: Memória, 2002.

STRECK, Lenio Luiz Concretização de direitos e interpretação da constituição. Boletim da Faculdade de Direito da Universidade de Coimbra-FDUC. vol. LXXXI. Coimbra: Coimbra Ed., 2005.

Verdade e consenso. Constituição, hermenêutica e teorias discursivas da possibilidade à necessidade de respostas corretas em direito. 2. ed. Rio de Janeiro: Lumen Juris, 2008.

Thomaz, Fernão de C. Fernandes. Da irresponsabilidade à responsabilização dos juízes. Revista da Ordem dos Advogados (Portugal). ano 54. vol. 2. Lisboa: Ordem dos Advogados, 1994.

URBANO, Maria Benedita. Responsabilidade jurídica: baralhar para governar. Boletim da Ordem dos Advogados. n. 27. Lisboa: Ordem dos Advogados, 2003.

Vale, André Rufino do. Neoconstitucionalismo. Revista de Direito Público. n. 14. Porto Alegre: Síntese/IOB/IDP, 2007.

VIlley, Michel. Esquisse historique sur le mot responsable. Archives de philosophie du droit. n. 22. Paris: Sirey, 1977.

VIEIRA, Oscar Vilhena. Supremo Tribunal Federal: jurisprudência política. São Paulo: Malheiros, 2002. 


\section{Pesquisas do Editorial}

\section{Veja também Doutrina}

- A interpretação constitucional como adaptação histórica do conteúdo normativo da Constituição, frente as cláusulas pétreas, de José Guilherme Carneiro Queiroz RDCl 52/182;

- Aproximação crítica entre as jurisdições de civil law e de common law e a necessidade de respeito aos precedentes no Brasil, de Luiz Guilherme Marinoni - RePro 172/175; e

- Constituição, interpretação e ideologia, de Rosmar Antonni Rodrigues Cavalcanti de Alencar - RT873/55. 